\title{
完全統合型数值人体モデルの概要と経気道曝露濃度解析
}

気道モデルを統合した数值人体モデルの開発 第 2 報

\section{OUTLINE OF COMPUTER SIMULATED PERSON WITH FULL INTEGRATION OF NUMERICAL RESPIRATORY TRACT AND PREDICTION OF RESPIRATORY EXPOSURE CONCENTRATION}

Development of computer simulated person with numerical respiratory tract model-part2

\author{
劉 城 準*, 伊藤一秀**
}

Sung-Jun YOO and Kazuhide ITO

\begin{abstract}
The effects of air pollution found in indoors and prevention of exposure to hazardous compounds are an important issue in the interest of public health. In this research, Computer Simulated Person (CSP) that integrated thermo-regulation and numerical respiratory tract model is developed for applying comprehensive assessment of health risk caused by indoor environmental quality problem. Especially, this paper (part 2) reports the internal integration procedure of virtual manikin and numerical respiratory tract by way of convective heat and moisture transfer analyses for improvement of thermo-regulation model. Furthermore respiratory exposure to contaminated air under different contaminant generation was studied using CSP and unsteady CFD technique.
\end{abstract}

Keywords : Computer Simulated Person, Numerical Respiratory Tract, Respiratory Exposure, CFD 数值人体モデル, 数值気道モデル, 経気道曝露, 計算流体力学

\section{1. 序}

本報(第2報)を含む一連の研究は, 鼻腔・口腔から気管支第4分岐程 度までの呼吸器系(気道)の幾何形状を詳細に再現した数值気道モデ ル (Virtual Airway) と実人体形状を詳細に再現したCFD解析用の数 值人体モデル(Virtual Manikin)を統合し，新たな数值人体モデル Computer Simulated Person (CSP)を開発することに主眼がある ${ }^{1)}$. 特 に気道モデル内の熱・物質輸送の詳細解析を基にした人体熱モデル の改良之, 呼吸器内の污染物質拡散場解析に伴う呼吸空気質・経気 道曝露濃度の予測精度改善を目的としてCSPの開発に取り組んでい る. 筆者らの研究グループは, メソスケールの気象解析から都市・ 建築スケールを介して人体内部までを連続して流体解析すること で，環境污染物質の個人暴露濃度を高精度に予測する解析手法の開 発に取り組んでおり, 本研究で開発するCSPは個人暴露濃度評価の ための中核技術である ${ }^{2)}$. また, 本研究で開発するCSPは人体熱モデ ルの他, 経気道暴露に伴う污染物質の体内動態を予測する生理的薬 物動態解析 (Physiologically Based Pharmaco- kinetic, PBPK)モデルと の統合を進めているが3)，本報(第2報)での解析結果は, PBPKモデル の入力条件(境界条件)となるものである.

前報(第1 報) ${ }^{1)}$ では，非定常人体熱モデルとしてGaggeらによる
2-Nodeモデル4)を数值人体モデルに組み込んだ上で, 数值気道モデ ル内の流れ場，温度場，湿度場解析を実施し，詳細なCFD解析にて 予測した気道内の対流熱伝達量, 湿気伝達量を人体熱モデルにフィ ードバックさせることで皮膚表面温度分布予測精度に与える影響 を検討した結果を報告した. 特に, 数值人体モデル(Virtual Manikin) と数值気道モデル (Virtual Airway)を別々にCFD解析しながら, 鼻腔 開口面を介してリアルタイムで境界条件の共有を行う外部連成手 法(External Coupling)を用いて数值的に統合解析実施した結果を報 告した。前報(第1報)では, この手法を連成解析型の統合数值人体モ デルと称した ${ }^{1)}$.

本報(第2 報)では, 数值人体モデル(Virtual Manikin) と数值気道モ デル (Virtual Airway)を連続したメッシュで完全に一体として作成 した完全統合型数值人体モデルの概要を紹介した上で，この完全統 合型数值人体モデルを適用した場合の人体熱モデル(2-Node モデ ル)の修正方法を示すと共に, 污染物質の濃度場解析を合わせて実施 することで, 呼吸空気質予測と経気道曝露濃度予測に関するケース スタディを行った結果を報告する。

2. 完全統合型数值人体モデル (CSP)
* 九州大学大学院 総合理工学府 博士課程 $\cdot$ 修士 (工学)

** 九州大学大学院 総合理工学研究院 准教授. 博士 (工学)
Ph. D. Candidate, IGSES, Kyushu Univ., M. Sci. Assoc. Prof., IGSES, Kyushu Univ., Dr. Eng. 
本報を含む一連の研究では, 完全統合型数值人体モデル (Model 1) と境界条件を共有させる連成解析型の統合型数值人体モデル (Model 2)の 2 種類を検討している. 後者の Model 2 に関しては, 前報(第 1 報)で開発概要の他, 人体熱モデル(Two-Node Model) と数值気道モ デルの組み込み方法を報告した ${ }^{1)}$. 本報(第 2 報)では, 完全統合型数 值人体モデル (Model 1)の概要と人体熱モデルとの連成解析, 経気道 曝露濃度予測への適用方法を報告する。

完全統合型数值人体モデルは連続したメッシュにて数值人体モデ ルと数值気道モデルを完全に一体化し，CFD 解析を実施する際には 気道内部空間から鼻腔・口腔を介して室内空間まで一連の解析空間 として扱うモデルである。解像すべき対象空間が室スケールから気 管支内の $\mathrm{mm}$ (ミリメートル)以下スケールまで広範になりメッシュ デザインに配慮が必要となることを除けば，特殊な数值解析上の技 術は要求されず，十分な計算機能力さえあれば実行可能なモデルと 云える.この完全統合型数值人体モデルの概要と鼻孔近傍のメッシ ユ分割の様子を Fig.1 に示す. Fig.1 は前報(第 1 報)で報告した完全統 合型数值人体モデルの概要図(Fig.4)の一部情報を更新して本報に再 掲するものである. 本研究では立位ならびに座位の 2 種類の条件で 完全統合型数值人体モデルを作成したが，本報では立位条件での解 析結果を示寸.

\section{3. 人体熱モデル(2-Nodel モデル)の統合}

前報(第 1 報) 1 )では, 非定常人体熱モデルとして Gagge らによる 2-Node モデルを対象とした上で, 数值気道モデル (Virtual Airway) 内の対流熱伝達量, 湿気伝達量解析結果を 2-Node モデルにリアルタ イムでフィードバックする外部連成手法(External Coupling)の概要 と解析例を報告した ${ }^{1)}$. 本報(第 2 報)で, 前節で示した完全統合型数 值人体モデル(Model1)を用いて気道内ならびに人体周辺環境を一 体・連続として解析するため, 境界条件を共通する連成解析型の統合 型数值人体モデル(Model 2)のように Script file を利用した境界条件 の受け渡しを実施せず, 気道内の対流熱伝達量, 湿気伝達量の解析 結果を直接人体熱モデル(2-node モデル)にフィードバックさせる. 2-Node モデルならびに気道モデル内解析結果を用いた呼吸による 顕熱損失 $C_{\text {res }}\left[\mathrm{W} / \mathrm{m}^{2}\right]$ ならびに呼吸による潜熱損失 $E_{\text {res }}\left[\mathrm{W} / \mathrm{m}^{2}\right]$ の修正 方法は前報(第 1 報)に詳細に記載されている ${ }^{1)}$.

\section{4. 呼吸空気質と経気道曝露濃度予測}

室内環境中に数值人体モデルを設置した上で, 気道モデルを連成 して解析することで, 室スケールの濃度分布から人体周辺・呼吸域周 辺に形成される不均一濃度分布, 加えて, 気道内の濃度分布までを 連続して解析することが可能となる. 境界条件を共有させる連成解 析型の統合型数值人体モデル (Model 2)を用いる場合には, 鼻孔面も しくは口腔の開口面で非定常不均一濃度分布情報を Script file にて 受け渡しを行うことで数值的に統合解析を実施した。本報で報告す る完全統合型数值人体モデル (Model 1)を用いる場合は, 特に追加の 設定無く経気道暴露濃度予測が実施できる.

\section{5. 数値解析の概要}

本報では, 単純なモデル空間内に人体モデルを設置した条件で, 特に完全統合型の数值人体モデル(Model 1)を用いて人体熱モデル

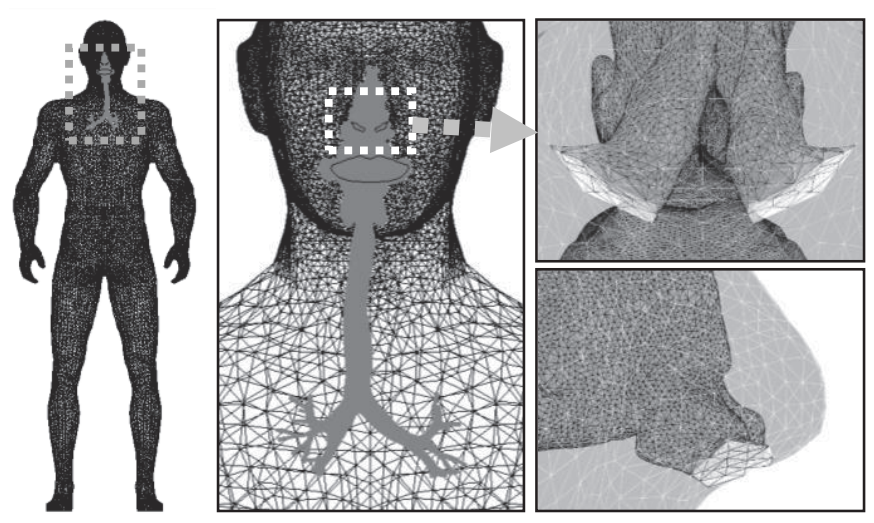

Fig.1 Grid design of Computer Simulated Person and details of nasal part
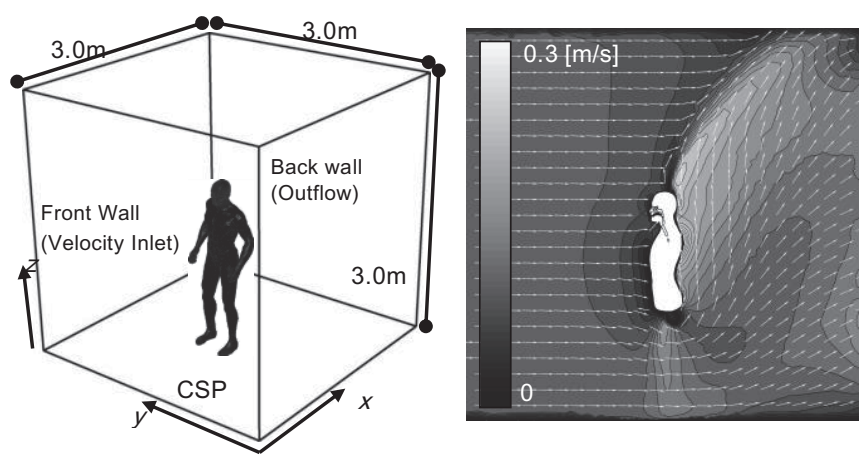

(1) Analytical domain

(2) Velocity distribution around CSP

Fig.2 Outline of the CFD Simulation

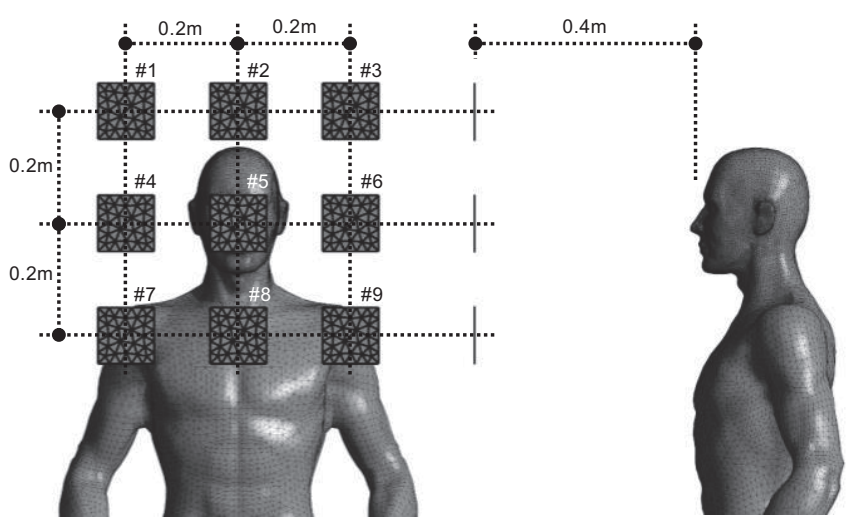

(1) Front view

(2) Left side view

Fig.3 The positions of the contaminant source

$(0.1 \mathrm{~m} \times 0.1 \mathrm{~m}$, total 9 planes $)$

(2-Nodel model) との連成解析, 経気道暴露濃度解析を実施する.

\section{1 解析対象空間の概要}

前報(第 1 報 $)^{1)}$ と同一の解析空間を Fig.2 (1) に示す。単純な $3 \mathrm{~m} \times 3 \mathrm{~m} \times 3 \mathrm{~m}$ の立方体空間の中心位置に数值人体モデルが立位状態 で設置されている条件である. 人体モデル正面から一様流の流入面, 人体モデル背後の面に流出面を想定し，室内には水平方向に一様流 が作出される単純な流れ場を設定した.

\section{2 流れ場解析の概要}

流れ場は人体表面ならびに気道内表面に形成される粘性底層まで 


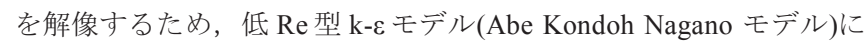
よる解析を実施する ${ }^{5)}$ ，計算アルゴリズムとして SIMPLE 法，移流 項の差分スキームとしてQUICK，その他は中心差分を用いる. 基本 的な流れ場解析条件は前報(第 1 報 $)^{1)}$ と同一である。単純室モデルの 流入面には平均流入風速 $U_{i n}=0.1 \mathrm{~m} / \mathrm{s}, T I$ (Turbulent Intensity) $=10 \%$ を 与え, 流出面は自由流出条件を与えた.

人体モデルの呼吸を再現するため, 本報では鼻孔開口面に仮想的 な流出入面を設定し, その仮想面に強制的な非定常の呼吸少イクル モデルを流入境界条件として設定する。これは鼻孔開口面に非定常 の移流風速成分と乱れを強制的に与えるもので，その時間変化を記

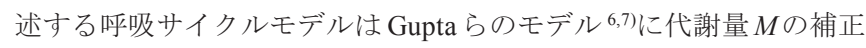
を施したモデル ${ }^{8)}$ を使用した．数值気道モデルの気管支細分岐の末 端部分は圧力境界条件を与えた。

\section{3 熱·物質輸送現象の解析概要}

室内環境要素として温度ならびに湿度を連成して解析する。人体 皮膚表面温度は人体熱モデルと室内環境との対流・放射連成解析の 結果として算出される. 単純室モデルの流入空気温湿度は $T_{i n}=25^{\circ} \mathrm{C}$, $\varphi_{i n}=50 \% \mathrm{RH}$ (絶対湿度で $0.009925 \mathrm{~kg} / \mathrm{kg}$ ') 一定を与え, 流出面では各 スカラ量に対して勾配ゼロ条件とした。数值気道モデル内壁の表面 温度はコア温度と一致していると仮定し, 2-Node モデルによるコア 温度 $T_{c r}$ を気道内表面温度として与えた. $T_{c r}$ は非定常解析によって 得られた值をリアルタイムで気道内表面温度としてフィードバック させており, 本解析では気道内での表面温度分布は考慮せず一様と して与えた. また, 気道内表面湿度は $\varphi_{\text {wall (airway) }}=99 \% \mathrm{RH}$ と仮定し, $T_{c r}$ と共に計算される絶対湿度を表面境界条件として与えた。

非定常呼吸を再現した際, 呼気(吐出側)の場合に気管支の各細分 岐の開口面が流入境界となり, 温度, 湿度に関しては何らかの境界 条件を与える必要がある。ここではコア温度 $T_{\text {in(airway })}=T_{c r}$, を気管支 各細分岐開口面の流入温度として与えると共に, 肺胞ではほぼ飽和 状態にあると想定して, $\varphi_{\text {in (airway) }}=99 \% \mathrm{RH}$ を与える. 吸気(吸入側) 条件の気管支の各細分岐の開口面は流出境界となり, この場合は自 由流出条件を与える.

また, 経気道暴露濃度の予測を行うために, 解析対象空間に仮想 的な污染物質(本報ではガス状污染物質として Passive Scalar 想定) の発生源を設置することで, 熱・水分の輸送方程式に加え, 污染物質 の輸送方程式も同時に解析した。污染物質発生源として, 人体の鼻 頭面から前方 $40 \mathrm{~cm}$ 位置に一定間隔を持つ 9 箇所の污染物質発生面 (\#1 \#9)を配置した。污染物質発生面では, 代表濃度(污染物質発生 量と解析領域に流入する空気量より計算される完全混合濃度)が 1 之 なるよう，発生面各セルに濃度を固定值として与えた。污染物質発 生位置と数值人体モデルの相対位置関係を Fig. 3 に示寸. 各污染物質 発生面は人体より上流側に設定されているため, 発生面の各々から Passive Scalar を想定した污染物質を定常発生させた場合には, 流入 空気に輸送されて人体呼吸域まで到達する条件を想定した注1)。この 污染物質発生面は, 特定の室内空気污染状況を想定したものではな く, 経気道暴露濃度予測シミュレーションの可能性を議論するため の仮想的な条件である. また, 数值気道モデルの内壁面では污染物 質濃度に対して勾配ゼロを与え, 気道内壁面吸着を無視した条件と した注 2 . 吸気モードの場合, 鼻孔より気道内に流入した污染物質は そのまま壁面吸着することなく気道内深部一輸送されるが, 呼気モ
Table 1 Numerical and boundary condition of CFD simulation

\begin{tabular}{|c|c|}
\hline $\begin{array}{l}\text { Turbulence } \\
\text { Model }\end{array}$ & $\begin{array}{l}\text { Low Re Number Type } k-\varepsilon \text { model } \\
\text { (Abe- Kondoh- Nagano Model, 3D Cal.) }\end{array}$ \\
\hline Mesh & $\begin{array}{l}\text { Virtual Airway (inside respiratory tract): } \\
7.6 \text { million tetrahedral mesh (Unstructured) } \\
\text { Analytical domain around the CSP: } \\
2.4 \text { million prism\&tetrahedral mesh } \\
\text { (Unstructured) }\end{array}$ \\
\hline Algorithm & SIMPLE (Unsteady) \\
\hline Scheme & Convection Term: QUICK \\
\hline $\begin{array}{l}\text { Inflow boundary } \\
\text { (Airway model) }\end{array}$ & $\begin{array}{l}Q_{\text {in }}=\text { see Figure } 3 \text { of part1 (unsteady) } \\
k_{i n}=3 / 2\left(U_{\text {in }} \times 0.05\right)^{2}, \varepsilon_{i n}=C_{\mu}{ }^{3 / 4} k_{i n}^{3 / 2} l_{i n} \\
T_{\text {air }}, \varphi_{\text {in }}: \text { feedback from CSP simulation }\end{array}$ \\
\hline $\begin{array}{l}\text { Inflow boundary } \\
\text { (Room model) }\end{array}$ & $\begin{array}{l}\text { Velocity Inlet, } \quad V_{i n, r}=0.1 \mathrm{~m} / \mathrm{s} \\
T_{i n, r}=298 \mathrm{~K}, \varphi_{i n, r}=50 \% \mathrm{RH}\end{array}$ \\
\hline $\begin{array}{l}\text { Outflow boundary } \\
\text { (Airway model) }\end{array}$ & $\begin{array}{l}\text { Boundary type : Pressure boundary } \\
\text { Backflow condition : } 309.8 \mathrm{~K}, 99 \% \mathrm{RH} \\
\text { Backflow contaminant concentration : } 0\end{array}$ \\
\hline $\begin{array}{l}\text { Outflow boundary } \\
\text { ( Room model) }\end{array}$ & $U_{\text {out }}=$ Free slip,$k_{\text {out }}=$ Free slip,$\varepsilon_{\text {out }}=$ Free slip \\
\hline $\begin{array}{l}\text { Wall treatment } \\
\text { (Airway model) }\end{array}$ & $\begin{array}{l}\text { Velocity: no slip } \\
\text { Temperature ; } T_{\text {wall surface }} \text { : } \\
\qquad \text { calculated by } 2 \text {-node } \operatorname{model}\left(T_{c r}\right) \\
\text { Humidity ; } \varphi_{\text {wall surface }}=99 \% \mathrm{RH} \\
\text { Contaminant: gradient zero }\end{array}$ \\
\hline $\begin{array}{l}\text { Wall treatment } \\
\text { (Virtual Manikin) }\end{array}$ & $\begin{array}{l}\text { Velocity: no slip } \\
\text { Temperature and humidity: } \\
\quad \text { calculated by } 2 \text {-node } \operatorname{model}\left(T_{s k}\right) \\
\text { Contaminant: Gradient zero }\end{array}$ \\
\hline $\begin{array}{l}\text { Wall treatment } \\
\text { (Room model) }\end{array}$ & $\begin{array}{l}\text { Velocity: no slip } \\
\text { Temperature, humidity and contaminant: } \\
\text { Gradient zero (adiabatic) }\end{array}$ \\
\hline $\begin{array}{c}\text { Contaminant } \\
\text { generation }\end{array}$ & Fixed concentration at generation point \\
\hline Others & $\begin{array}{l}\text { Radiation model: S2S model, Ray tracing method } \\
\text { Metabolic rate } M=75.5 \mathrm{~W} / \mathrm{m}^{2} \\
\text { Body weight } W=65 \mathrm{~kg} \\
\text { Body surface area } B S A=1.745 \mathrm{~m}^{2}\end{array}$ \\
\hline
\end{tabular}
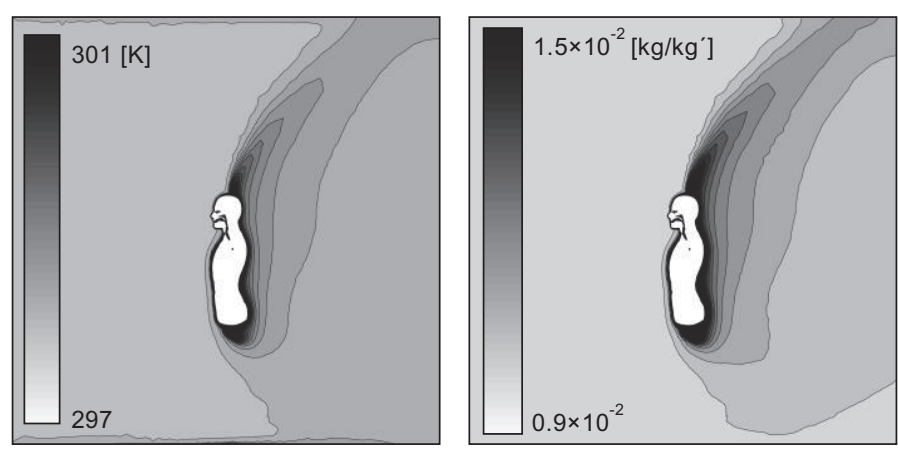

Fig.4 Temperature and humidity distributions around CSP

ードの場合, 気管支第四分岐端部から濃度ゼロの空気が流入する条 件とし，この空気により気道内濃度が希釈されて濃度低減する条件 で解析を行う注 3).

数值解析条件ならびに境界条件の一覧を Table 1 に整理して示寸. 数值人体モデル皮膚表面と単純室モデルの周壁との長波長放射によ る熱交換は, ANSYS/Fluent の S2S モデルを用いて連成解析した ${ }^{9}$. 


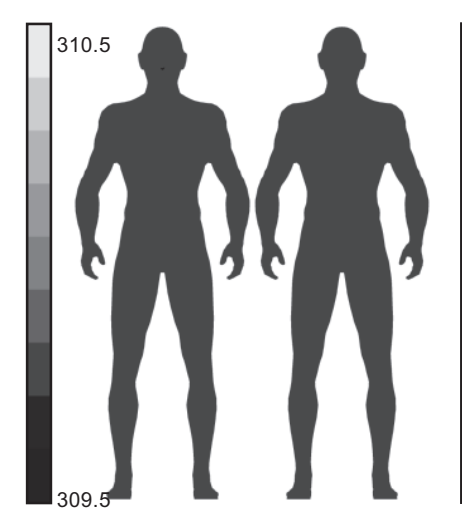

(1) Core temperature $[K]$

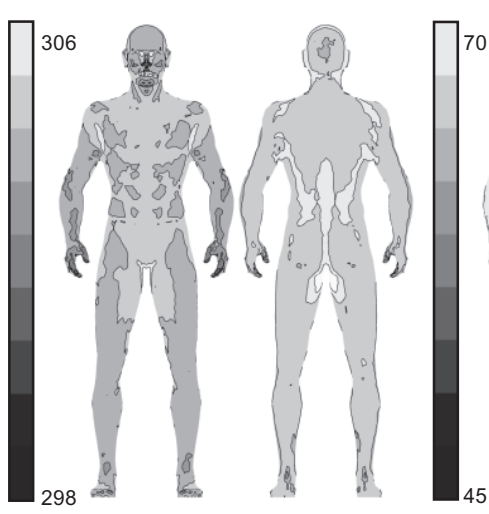

(2) Skin surface temperature $[\mathrm{K}]$

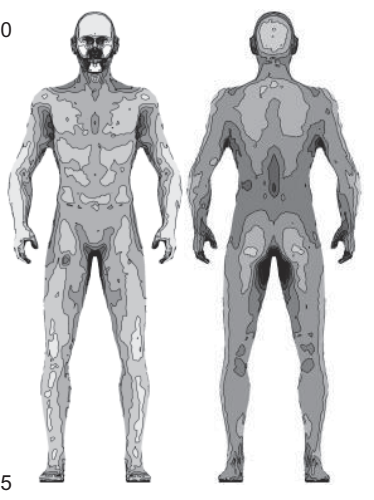

(3) Sensible heat flux $\left[\mathrm{W} / \mathrm{m}^{2}\right]$

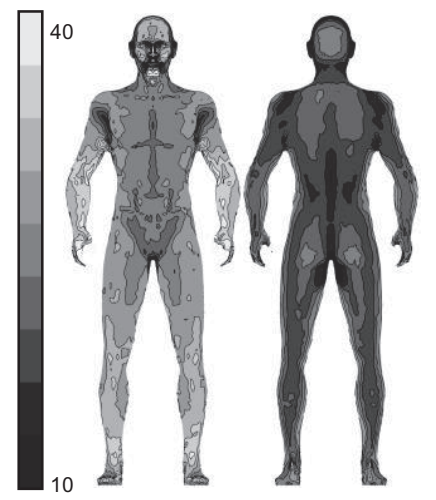

(4) Latent heat flux[W/m²]

Fig.5 Result of CFD Simulation integrated with Virtual Airway analysis

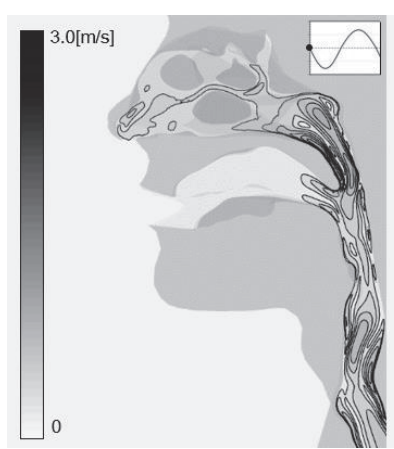

(1) $t=0 s$

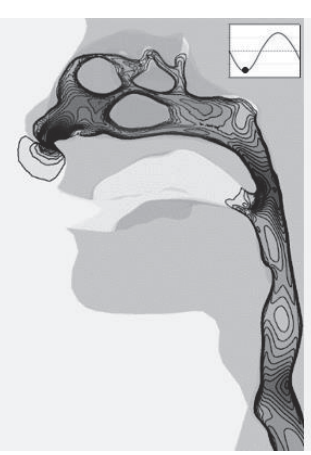

(2) $t=1 \mathrm{~s}$ (Maximum inflow)

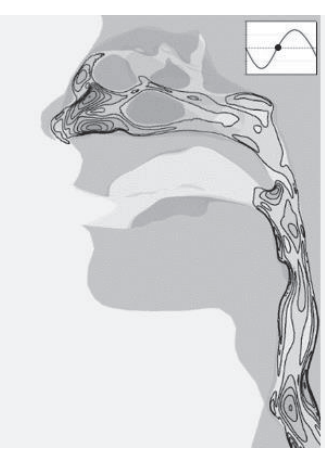

(3) $t=2 s$

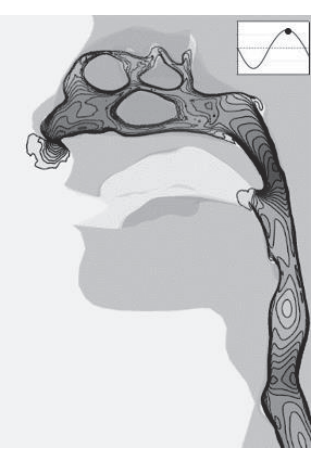

(4) $t=3 s$ (Maximum outflow)

(a) Scalar velocity distributions

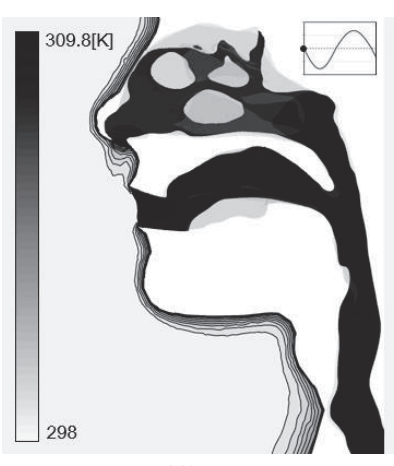

(1) $t=0 s$

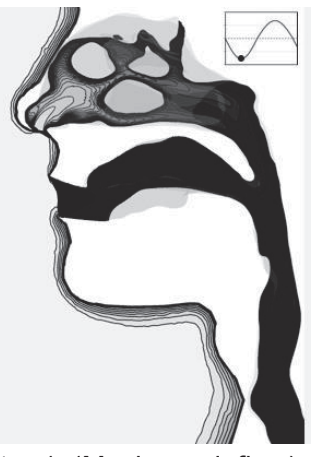

(2) $t=1 \mathrm{~s}($ Maximum inflow)

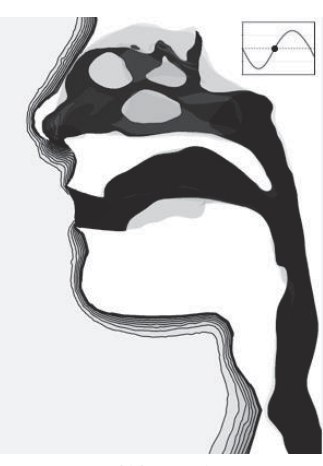

(3) $t=2 s$

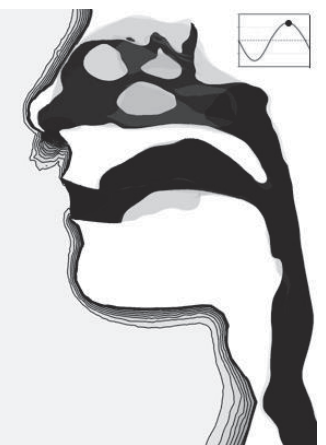

(4) $t=3 s$ (Maximum outflow)

(b) Temperature distributions

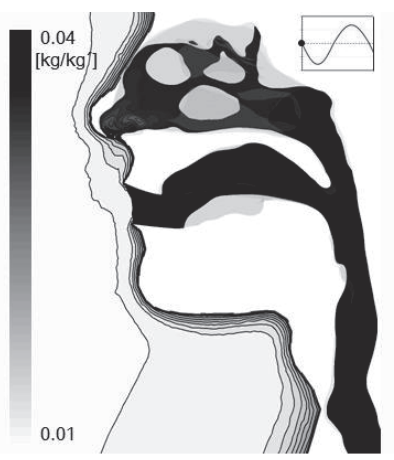

(1) $t=0 s$

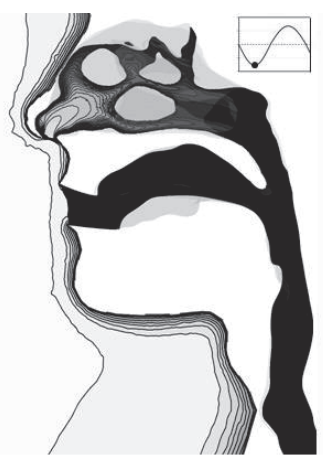

(2) $t=1 \mathrm{~s}$ (Maximum inflow)

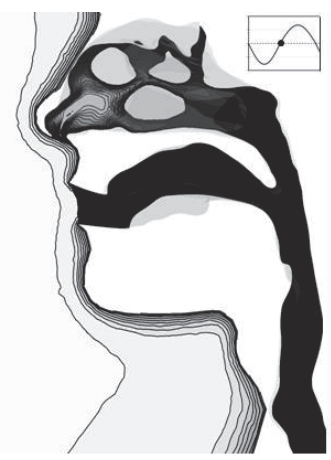

(3) $t=2 s$

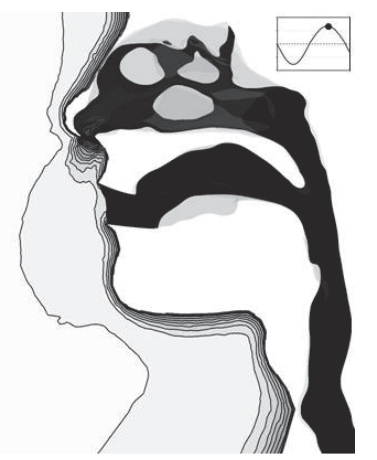

(4) $t=3 s$ (Maximum outflow)

(c) Absolute humidity distributions

Fig.6 Velocity, temperature and humidity analysis results inside the Virtual Airway (1 breathing cycle) 


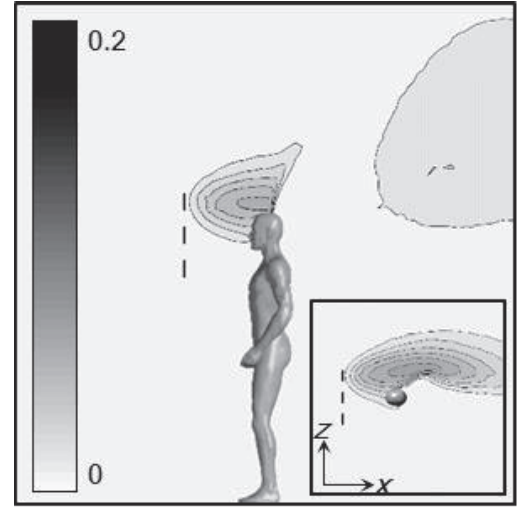

(1) Point \#1

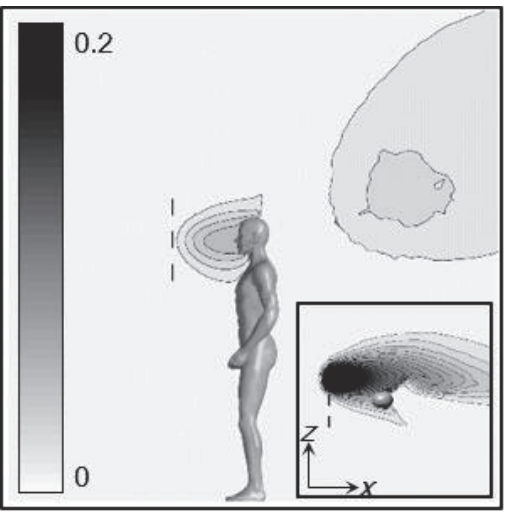

(4) Point \#4

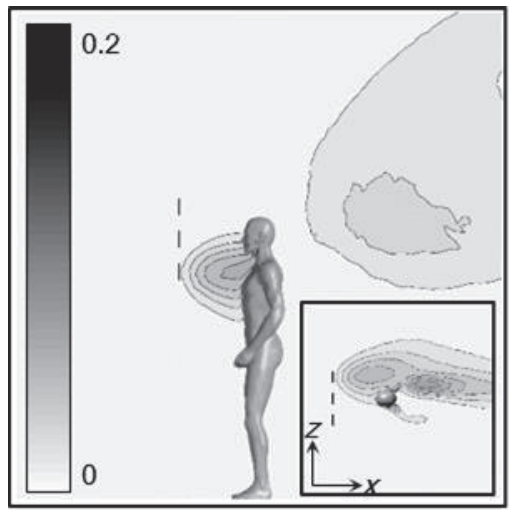

(7) Point \#7

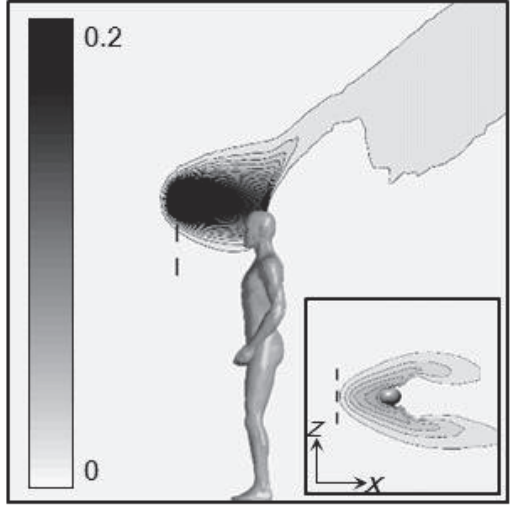

(2) Point \#2

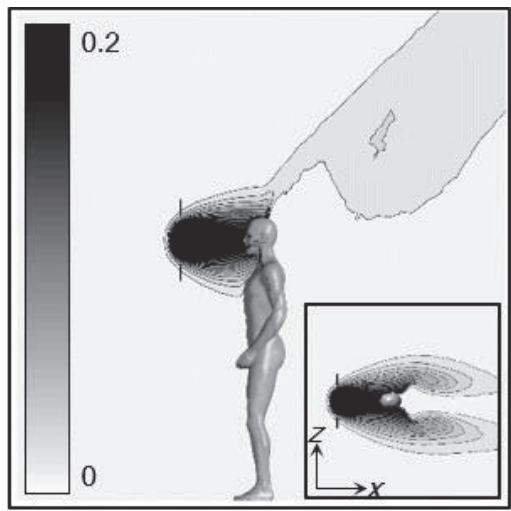

(5) Point \#5

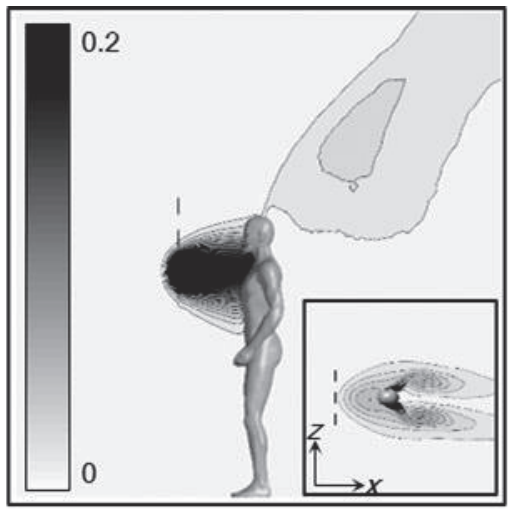

(8) Point \#8

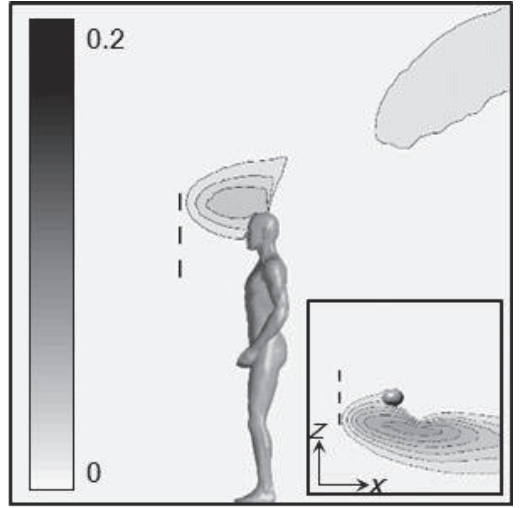

(3) Point \#3

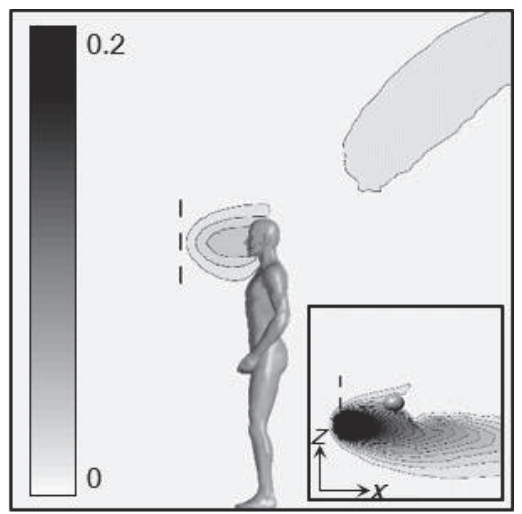

(6) Point \#6

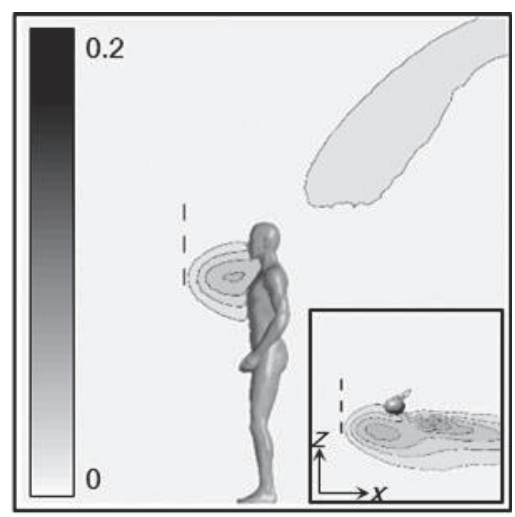

(9) Point \#9

Fig.7 Distribution of contaminant concentration around CSP $(y=1.5 \mathrm{~m}$, Concentration of generation point $=1.0)$

\section{6. 数値解析結果}

6.1 統合型数值人体モデルを用いた人体熱モデルとの連成解析結果

人体モデル周りの温度分布ならび湿度分布解析結果を Fig.4 に示

す．人体モデル前面から一様流が流入する条件であるが，移流風速 が小さいため $\left(U_{i n}=0.1 \mathrm{~m} / \mathrm{s}\right)$, 人体発熱に伴う熱上昇流が人体上部に観 察され，不均一な温度分布ならびに湿度分布が確認される。

既報(第 1 報)では，境界条件を共通する連成解析型の統合型数值 人体モデル (Model 2)による同様の解析結果を示したが，今回の完全 統合型数值人体モデル (Model 1)を用いた人体周辺流れ場, 温度場, 湿度場の解析結果は同一の結果が得られた。境界条件は同一である ことから完全に同一結果となることが必須であり，計算精度が確認 されたと言い換えることも出来る.

Fig.5 には数值人体モデル皮膚表面温度 $T_{s k}$ 分布, コア層の温度 $T_{c r}$
分布, 顕熱放散フラックスならびに潜熱放散フラックスの解析結果 (人体皮膚表面での分布図)を示す.人体表面での顕熱・潜熱フラック スには不均一分布が確認されると共に, 特に非定常呼吸少イクルを 再現した影響で, 顔の部分, とくに鼻の周辺で熱・潜熱フラックスの 不均一分布が認められる。この結果も既報(第 1 報)と同一である.

Fig.6には数值気道モデル内の流れ場, 温度場, 湿度場解析結果の 一例を示す. 呼吸サイクルに合わせて時間変化する流れ場等の様相 を示している. 気道内には不均一な流れ場形成に伴い, 明確な温度 分布ならびに湿度分布が形成されていることが見て取れるが，この 結果も既報(第 1 報)と同一である.

\section{2 統合型数值人体モデルを用いた経気道暴露濃度解析結果}

Fig.7 に室内で仮想的な污染物質をポイントで定常発生させた場 合の人体周辺の濃度分布解析結果を示寸. 当然の結果であるが, 污 


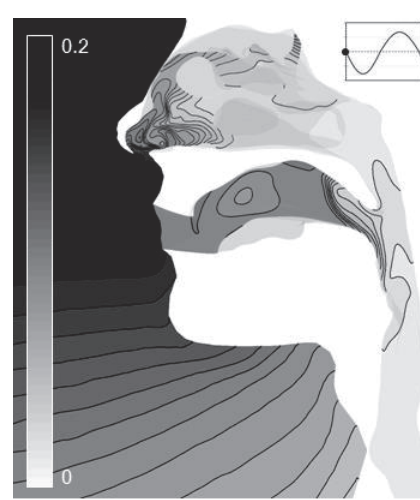

(1) $\mathrm{t}=0 \mathrm{~s}$

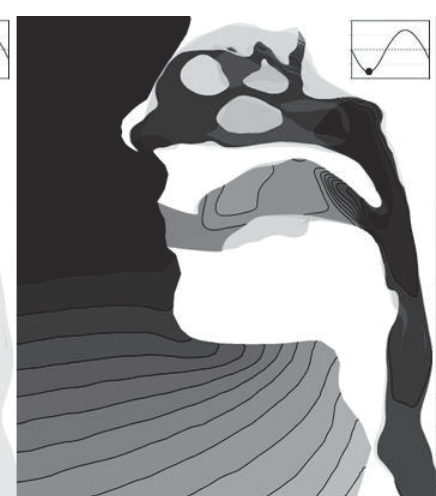

(2) $\mathrm{t}=1 \mathrm{~s}$ (Maximum inflow)

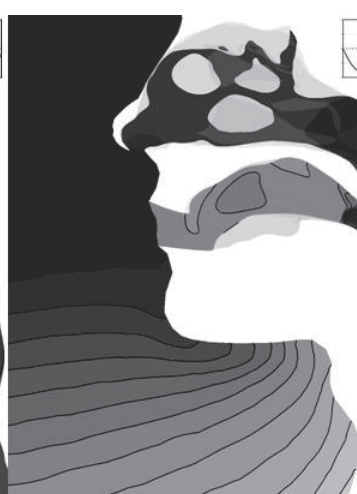

(3) $\mathrm{t}=2 \mathrm{~s}$

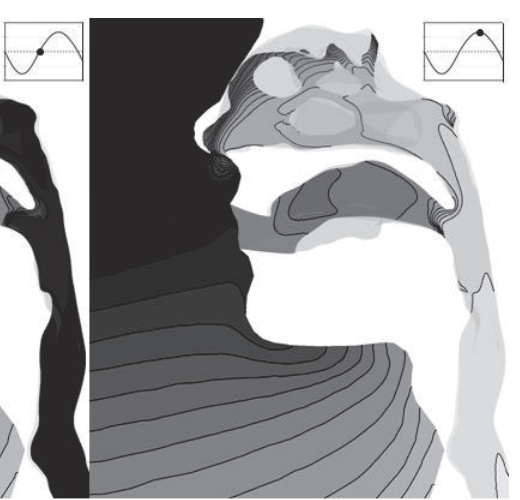

(4) $t=3 s($ Maximum outflow)

Fig.8 Time series of contaminant concentration(\#5) distributions inside Virtual Airway (1 cycle, Concentration of generation point = 1.0)

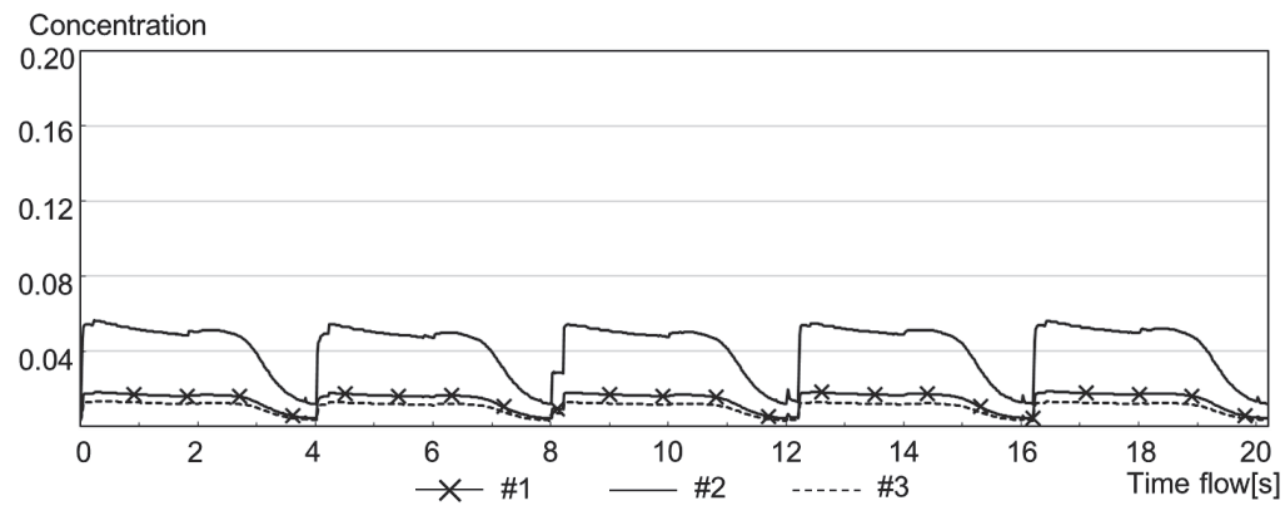

(1) Contaminant concentration generated from point \#1, \#2 and \#3

Concentration

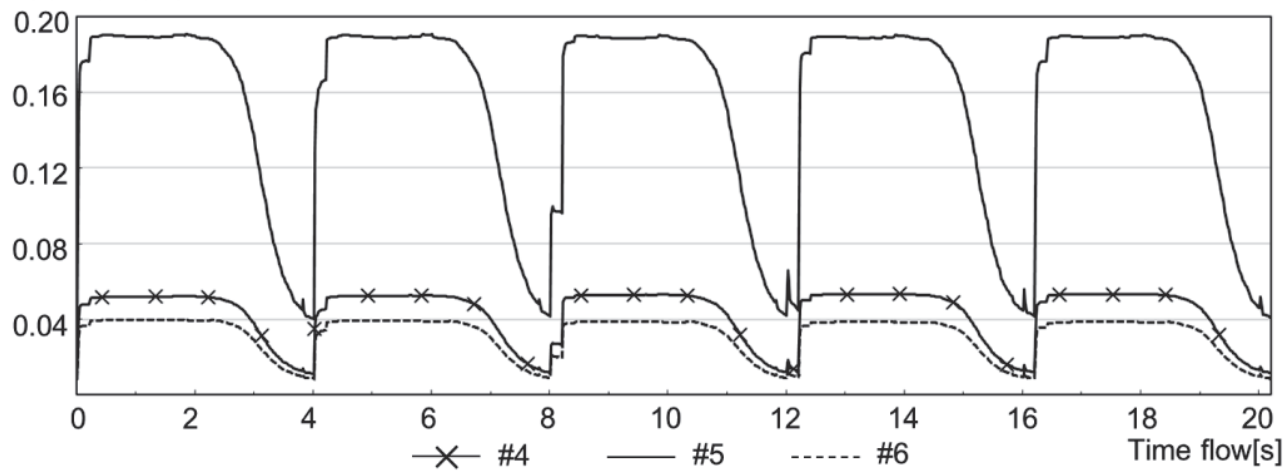

(2) Contaminant concentration generated from point \#4, \#5 and \#6

Concentration

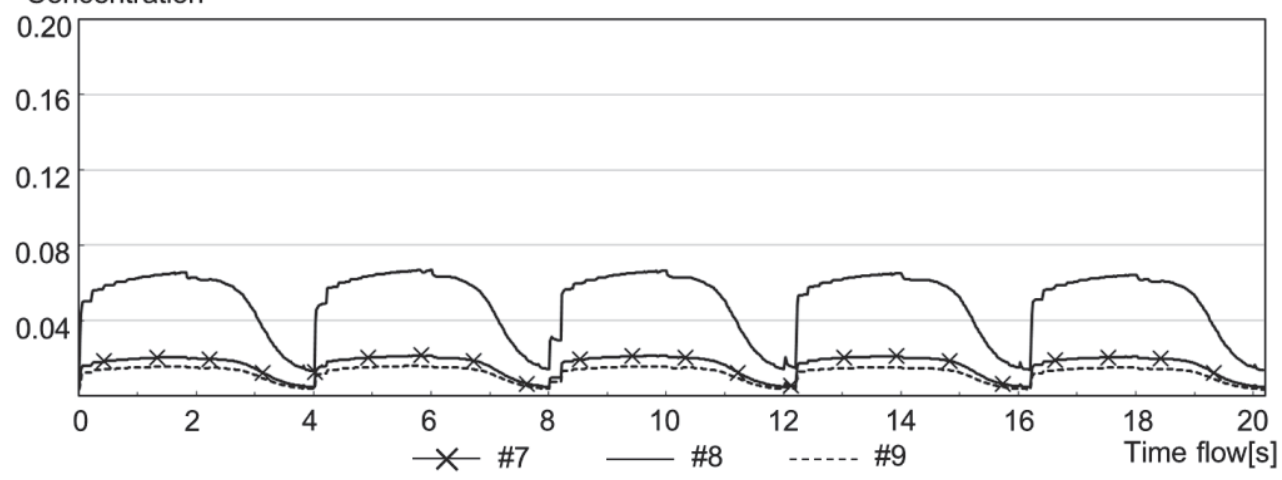

(3) Contaminant concentration generated from point \#7, \#8 and \#9

Fig.9 Time series of contaminant concentration at nostril surfaces $($ Concentration of generation point $=1.0)$ 


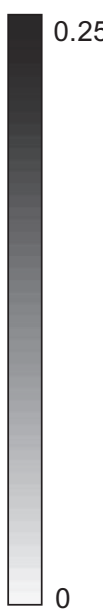

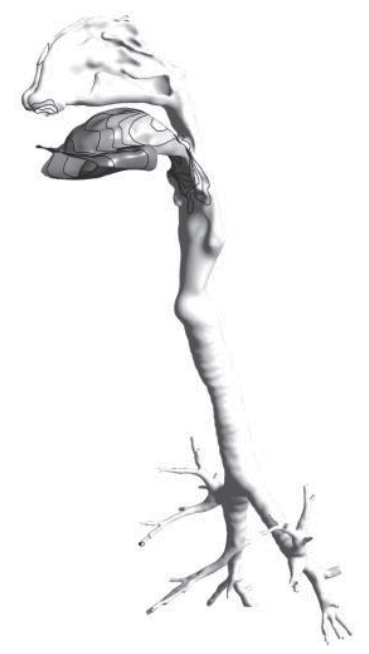

(1) $t=0 s$

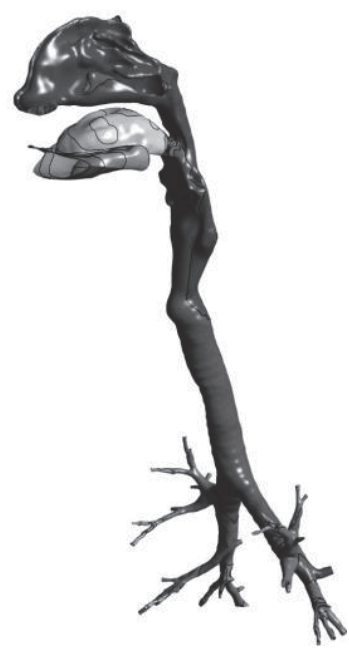

(2) $t=1 \mathrm{~s}$ (Maximum inflow)

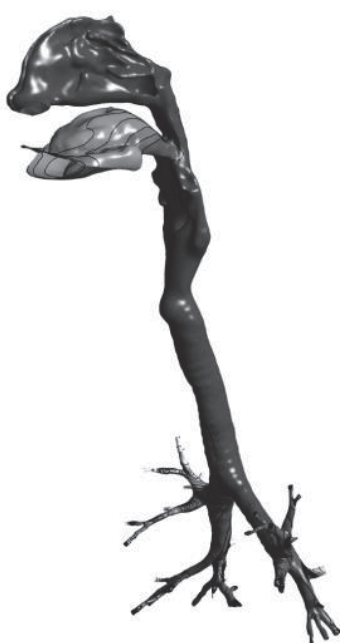

(3) $t=2 s$

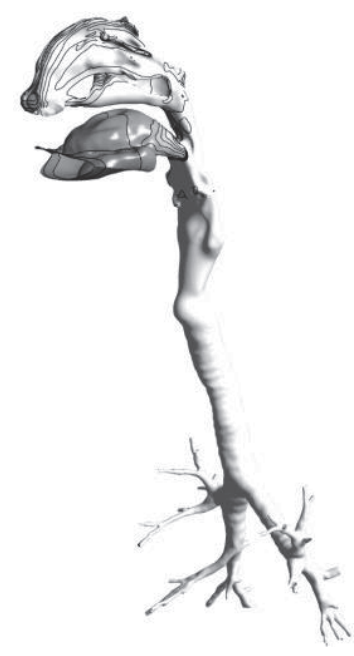

(4) $t=3 s$ (Maximum outflow)

Fig.10 Inner wall surface contaminant concentration distributions (\#5) of human airway (1 breathing cycle)

染物質発生面の設定位置を変化させることで，室内に形成される污 染物質分布に差違が確認出来る. Fig. 8 には数值気道モデル内の污染 物質濃度分布の解析結果を呼吸サイクルに合わせて時間変化する様 相がわかるように図示している。ここでは，特に 9 箇所想定した污 染物質発生面の中で，人体鼻頭と同一高さに設定した発生面\#5 から の污染物質発生を仮定した場合の気道内濃度変化を示している. 本 解析では口呼吸条件は考慮していないが, 咽頭部より口腔内に逆流 した污染物質が口腔内に滞留し, 相対的に高濃度領域となっている 様子が確認できる.

Fig.9 には鼻孔開口面位置における污染物質濃度の時間変化を示 す、気道モデル内壁面での污染物質沈着は無視した上で，気管支第 四分岐の末端部からは(即ち肺方向からは)污染物質濃度 0 の空気が 気道内に供給される条件を与えたため, 鼻腔面の污染物質濃度が呼 吸サイクルの変化に少し遅れて変動する様子が確認できる.

Fig.10 は呼吸サイクルの時間変化による経気道内表面の污染物質 暴露濃度分布を示している. 吸気モードである $t=1 \sim 2$ の間に気道内 に污染物質が移流し, 気道内表面の污染物質濃度が上昇する様子が 確認できる. また, 呼気モードである $t=2 \sim 3$ の結果では, 肺から戻 る濃度ゼロの空気により気道内に滞留していた污染物質が希勫・排 出される様子も確認できる.

\section{7. 考察と今後の課題}

本研究では, 鼻腔・口腔から気管支第 4 分岐程度までの呼吸器系(気 道)の幾何形状を詳細に再現した数值気道モデル (Virtual Airway) と 実人体形状を詳細に再現した CFD 解析用の数值人体モデル(Virtual Manikin)を統合することで, 新たな数值人体モデル Computer Simulated Person (CSP)の開発に取り組んだ結果を報告した。特に本報(第 2 報)では, 数值気道モデルと数值人体モデルをメッシュレベルで結 合させた完全統合型の数值人体モデルを提案し, 詳細な気道内熱・ 水分移動解析結果を用いた非定常人体熱モデル(ここでは 2-Node model)の修正方法, 経気道暴露濃度予測手法に関して報告した。

本報での解析事例より, 室内に形成される不均一濃度場の性状や, 非定常呼吸サイクルの再現が経気道暴露濃度の予測結果に一定の影
響を与えることを定量的に確認した。 非構造系格子の使用が可能な 汎用 CFD コードの使用が一般化しており, 計算負荷が増大寸る点を 除けば, 研究開発分野で完全統合型の数值人体モデルを使用するこ とに特段の問題は無く, 室内空気質問題に起因する経気道暴露濃度 予測や評価が求められる場合の環境評価ツールとしての利用が期待 される. 特に, 環境設計の高度化に伴い, その制御対象が室全体か ら居住域等の局所領域にシフトしており, さらには個人をターゲッ トにしたパーソナル空間の個別制御の重要性も指摘されている.こ のような個人を対象とした究極の個別制御を行う場合の環境設計段 階で, 本研究成果が利用できる可能性がある.

本報(第 2 報)で得られた知見を整理すると以下となる.

1)当然の結論ではあるが, 完全統合型数值人体モデル (Model 1) と境 界条件を共通する連成解析型の統合型数值人体モデル (Model 2) の 2 種類の数值人体モデルを対象として同一の人体熱モデル $(2$ Node model)を適用した解析を実施した結果, 人体皮膚表面温度, コア温度, 顕熱・潜熱フラックスの解析結果は同一となった. 両者 は計算負荷のみが異なる。

2)数值気道モデル内の顕熱・潜熱移動を CFD 解析にて詳細解析した 上で，人体熱モデルにフィードバックする連成解析手法を示し， 解析例を示したが, 静穏環境条件下での単純立位条件の代謝量 $M$ の条件下では, 既往モデルとの有意な差異は確認できなかった. しかしながら，污染物質を模擬した Passive Scalar を対象とした濃 度場解析を実施した結果, 呼吸域周辺の不均一濃度分布に加え, 気道モデル内の不均一濃度分布ならびに経気道曝露濃度レベル. 位置に関する詳細情報を得ることが出来た。この解析手法は, 対 象とする污染物質を特定することで, 経気道曝露濃度解析として の実質的な意味が向上する. 気道モデル内表面での污染物質沈着 モデルの高精度化と具体的な曝露条件を想定した解析は今後の課 題である.

\section{謝 辞}

本研究の一部は科学研究費補助金(課題番号21676005)の助成を受 けたものである. 記して深甚なる謝意を示す. 
注 1) 本報では, 経気道暴露濃度予測の数值解析を実施するため, ガス状の 污染物質を仮定した上で, 空気と物性が同一であると仮定する Passive Scalar 想定してスカラ量の輸送方程式を解く.非定常呼吸を再現した 気道内流れ場の Reynolds 数が $R e=2000$ を超えることから, 気道内拡散 場は乱流拡散が卓越し, Passive Scalar での解析結果は, 各種のガス状 污染物質を対象とした濃度分布解析結果の良い代表例となっていると 考えられる.

注 2）気道モデル内壁面に対する污染物質の吸着・沈着性状を正確に再現する 数理モデルは, 現時点では存在しない，極端な境界条件の一つとして 本報で使用した勾配ゼロ型があり, もう一つの境界条件として, 表面 濃度ゼロ型がある，後者の場合は気道モデル内壁面を完全吸着面と見 な寸もので, 気道内表面が湿潤である場合には，第一次近似として良 い仮定とも推察される。本報での解析は気道モデル全体での污染物質 の輸送現象をダイナミックに観察するため, 即ち肺側から気道内に移 流してきた濃度ゼロの空気による気道内のパージ効果を確認するため, 壁面に勾配ゼ口型を採用した。気道内壁面での気相濃度と沈着相濃度 の関係のモデル化に関しては, PBPK モデル開発に関連する分野で研究 が進められており,この分野での成果を待って CFD 解析への統合を進 める必要がある ${ }^{3)}$.

注 3) 肺胞での污染物質沈着量を正確に予測する数理モデルは現時点では存 在しない，経気道暴露リスクを最大の安全側で評価する場合には，肺 胞まで到達した污染物質が完全吸収され, 呼気モードでは, 肺胞から は污染物質濃度ゼロの空気が気道内に戻される, との想定を採用する ことになる。これが本報で気管支第四分岐位置で呼気モードの際に濃 度ゼロの流入を想定した理由である。この点では, 本報での解析例は 極端に単純化した境界条件の下で実施した経気道暴露濃度予測シミュ レーションのデモンストレーションのレベルに留まっている, 医学・ 生理学分野での知見整備に合わせ, 数值解析の境界条件の高精度が今 後の課題である.

\section{参考文献}

1) Sung-Jun Yoo, 伊藤一秀 : 数值気道モデル内の対流熱伝達解析による人 体熱モデルの改良 気道モデルを統合した数值人体モデルの開発 第 1 報, 日本建築学会環境系論文集 第 80 巻 第 709 号, pp.229-238, 2015.3

2) Kazuhide Ito: Integrated Numerical Approach of CFD and Epidemiological Model for Multi-scale Transmission Analysis in Indoor Spaces : Indoor and Built Environment; 23 (7), pp.1029-1049, 2014

3) 伊藤一秀:経気道暴露を前提とした PBPK-CFD 手法による健康リスク予 測に関する現状と展望 : 日本建築学会九州支部研究発表会・研究報告, pp225-228, 2015.3

4) Gagge, A.P., Fobelets, A.P. and Berglund, L.G. A Standard Predictive Index of Human Response to the Thermal Environment, ASHRAE Transactions 92, pp709-731, 1986

5) Abe, K., Kondoh, T., A new turbulence model for prediction fluid flow and heat transfer in separating and reattaching flows-I. Flow field calculations, Journal of Heat and Mass Transfer 37: pp.139-151, 1994

6) Gupta, J.K., Lin, C.-H., and Chen, Q. Flow dynamics and characterization of a cough: Indoor Air 2009; 19: pp.517-525, 2009

7) Gupta, J.K., Lin, C.-H., and Chen, Q. Characterizing exhaled airflow from breathing and talking: Indoor Air 2009; 20: pp31-39, 2009

8) Yosuke Kadota, Toshiki Matsuo, Sung-Jun Yoo, Nguyen Lu Phuong, Kazuhide Ito : Development of Computer Simulated Person with Numerical Airway model, Part 3 Breathing Air Quality Prediction by Improved Unsteady Breathing Flow Model: Indoor Air 2014, Paper ID: HP0732, 2014

9) ANSYS/ Fluent ver 14.5, User Manual, 2014 
OUTLINE OF COMPUTER SIMULATED PERSON WITH FULL INTEGRATION OF NUMERICAL RESPIRATORY TRACT AND PREDICTION OF RESPIRATORY EXPOSURE CONCENTRATION

Development of computer simulated person with numerical respiratory tract model-part2

\author{
Sung-Jun YOO* and Kazuhide ITO** \\ * Ph. D. Candidate, IGSES, Kyushu Univ., M. Sci. \\ ** Assoc. Prof., IGSES, Kyushu Univ., Dr. Eng.
}

The impacts of exposure to hazardous chemical compounds on indoor residents are an important issue in the interest of public health. In this research, Computer Simulated Person (CSP) that reproduced detail human geometry and integrated numerical respiratory tract model is developed for applying comprehensive assessment of health risk caused by indoor environmental quality problem. The concrete objective of this research series (Part 1and Part 2) were to develop a comprehensive and universal computer-simulated person (CSP) that integrates thermo-regulation and respiratory tract models for indoor environmental quality assessment. The previous paper (Part 1) of this research series had reported the external coupling procedure of virtual manikin and numerical respiratory tract by way of convective heat and moisture transfer analyses and also the improvement of thermo-regulation model by detail numerical analysis in numerical respiratory tract. This paper (Part 2) reports the development of full integrated CSP model that uses the complete and comprehensive human body model incorporating the airway model.

A virtual manikin, which reproduces the actual shape of the human body for computational fluid dynamics (CFD) simulation, was integrated with a thermo-regulation model to control the skin surface temperature of the human body. A respiratory tract model that reproduces detail geometry and unsteady breathing cycle was also integrated into the virtual manikin. Here, the two-node model proposed by Gagge et al. was integrated with the CSP.

For targeting full integrated CSP model, detail CFD analysis of flow, temperature and humidity distributions were conducted not only around human model but also inside numerical airway model with the low Re-type $\mathrm{k}-\varepsilon$ model. Radiative heat transfer analysis was also carried out with the S2S model. An analytical domain with dimensions of $\mathrm{x}=3.0 \mathrm{~m}, \mathrm{y}=3.0 \mathrm{~m}$, and $\mathrm{z}=3.0 \mathrm{~m}$ was centered on a standing virtual manikin, and simple and uniform flow boundary conditions with a supply inlet flow from the floor and exhaust outlet flow from the ceiling were assumed.

In addition, 9 contaminant source points was created in front of nostril surface of the virtual manikin in order to analyze the respiratory exposure. And they have equal interval of $20 \mathrm{~cm}$ between the sources. The contaminant was generated from all of the source points with steady state.

As a result of inhalation exposure analysis, high concentration was confirmed at the whole wall surface of airway model and it was changed with the flow of the unsteady breathing cycle. In this analysis, gradient zero type (adiabatic) wall surface condition was used and hence transported contaminant through nostril surface was directly transported as far as the bronchus.

In order to analyze the respiratory exposure in an indoor environment, reproducing the respiratory tract and breathing cycle are critically important to the development of a CSP. Heat and mass transfer analysis and the feedback of these simulation results also have great potential to help improve the thermo-regulation model of a CSP. This paper simply presents a demonstration of a CSP with the respiratory tract, which needs to be validated in future stage. 